\title{
Re-engaging with Primary Mathematics Through Sustained Professional Development: A Case Study
}

\author{
Catherine Attard \\ Centre for Educational Research \\ University of Western Sydney
}

\begin{abstract}
This paper reports on aspects of a case study of sustained professional development to improve teacher and student engagement with mathematics. Teachers from Grades 3 to 6 in one Western Sydney primary school were involved with a professional development program over the course of 18 months. Prior to this, the teachers limited opportunities to engage with any mathematics-related professional development. The professional development program resulted in improved teacher engagement and the development of a community of practice within the school. Findings from the study align with recommendations from literature that teachers must be provided with opportunities for continuing professional development that is self-nominated and focused on individual needs as well as group needs.
\end{abstract}

Keywords: professional development, primary school, primary mathematics, teacher engagement, community of practice

\section{Introduction}

In countries where standards-based mathematics education is mandated, the demand for high levels of student engagement is heightened (Rimm-Kaufman, Baroody, Larsen, Curby, \& Abry, 2014). In Australia, curriculum documents such as the Australian Curriculum: Mathematics (Australian Curriculum and Reporting Authority [ACARA], 2017) and the Mathematics K-10 Syllabus (Board of Studies NSW, 2012) provide guidance on the mathematical content that has to be taught and the mathematical processes such as problem solving, reasoning, and communication that students are expected to use. However, these documents provide no support in relation to how teachers should teach these skills and concepts in a manner that promotes high student engagement that ultimately results in improved student learning outcomes.

Often, teachers rely on Professional Development (PD) opportunities to develop new strategies for engaging students with mathematics, yet for some, such opportunities are limited. In this paper, a case study involving a group of teachers from one Western Sydney school, Springvale Public School, will be presented. The teachers in this school had previously received either limited, or no PD in mathematics due to a previous school leadership team. This, coupled with low levels of student achievement and engagement, resulted in teachers who were disengaged with the teaching of mathematics. A new school principal and additional government funding led to the implementation of a sustained PD, insitu program of PD for all teachers in Grades 3 to 6 and in partnership with two university academics who specialized in primary mathematics education. Data was collected during the 
program and will be used here to explore whether this model of sustained PD enhanced the teachers' engagement with mathematics.

\section{Engagement and Mathematics}

The term engagement is used in education to describe students' levels of involvement with teaching and learning. There are numerous definitions of engagement in the literature, however for the purpose of this paper, engagement is defined as multi-dimensional, operating at cognitive, emotional, and behavioral levels (Fredricks, Blumenfeld, \& Paris, 2004). Viewed this way, engagement occurs with, and can be defined as the coming together of all three dimensions: cognitive, affective, and operative (Fair Go Team NSW Department of Education and Training, 2006; Munns \& Martin, 2005), (in line with Fredricks et al.'s cognitive, behavioral, and emotional engagement) that leads to students valuing and enjoying school mathematics, and seeing connections between school mathematics and their own lives beyond the classroom.

The Framework for Engagement with Mathematics (FEM) introduced by Attard (2014) (Figure 1) was devised to assist teachers in planning engaging learning experiences in mathematics. In this study, it was used as a foundation for the PD provided to the teachers and as a lens for analyzing the data and helping to understand whether the PD program was effective in achieving its goals.

\section{Framework for Engagement with Mathematics}

In an engaging mathematics classroom, positive pedagogical relationships exist where:

- students' backgrounds and pre-existing knowledge are acknowledged and contribute to the learning of others

- the teacher is aware of each student's mathematical abilities and learning needs

- interaction amongst students and between teacher and students is continuous

- the teacher models enthusiasm and an enjoyment of mathematics and has a strong pedagogical content knowledge

- feedback to students is constructive, purposeful and timely

In an engaging mathematics classroom, engaging pedagogical repertoires mean:

- there is substantive conversation about mathematical concepts and their applications to life

- tasks are positive, provide opportunity for all students to achieve a level of success and are challenging for all

- students are provided an element of choice

- technology is embedded and used to enhance mathematical understanding through a studentcentred approach to learning

- the relevance of the mathematics curriculum is explicitly linked to students' lives outside the classroom and empowers students with the capacity to transform and reform their lives

- mathematics lessons regularly include a variety of tasks that cater to the diverse needs of learners

Students are engaged with mathematics when:

- mathematics is a subject they enjoy learning

- they value mathematics learning and see its relevance in their current and future lives

- they see connections between the mathematics learnt at school and the mathematics used beyond the classroom

Figure 1. Framework for engagement with mathematics (Attard, 2014) 
The low levels of student engagement with mathematics have been of concern to Australian and international mathematics educators and stakeholders for several decades. The National Numeracy Review (Commonwealth of Australia, 2008) found many students fail to enjoy or recognize the personal relevance of mathematics and often choose to discontinue their study of mathematics beyond the compulsory years. The reasons students make the decision not to participate or engage in mathematics are varied. However, research on student engagement with mathematics (Attard, 2011, 2012) indicated that during the primary and middle years, teachers have the most influence on the engagement of students.

Given that teachers have so much influence on the engagement of students, it makes sense to assume that when teachers become disengaged with the teaching of mathematics, the likelihood of students becoming and remaining engaged significantly decreases. Hence, the priority of the PD program was to improve the teachers' levels of engagement with mathematics.

\section{Defining Professional Development}

In recent times the term 'professional learning' has come to be used interchangeably with the term 'professional development'. For the purpose of this report it is important to explore the two terms and provide a definition of the term PD as it pertains to this study.

Although used interchangeably, professional learning and PD have been differentiated in recent literature (Mayer \& Lloyd, 2011), with a noticeable shift away from 'development' towards 'learning'. Knapp (2003, as cited in Mayer \& Lloyd, 2011, pp. 3-4) defines PD as "the full range of activities, formal and informal, that engage teachers or administrators in new learning about their professional practice" (p. 112), while professional learning refers to "changes in thinking, knowledge, skills, and approaches to instruction that form practicing teachers or administrators' repertoire” (pp. 112-113).

In acknowledging the integral relationship between professional learning and PD, Mayer and Lloyd (2011) cited a definition from Day and Sachs (2004, as cited in Mayer \& Lloyd, 2011) that includes both development and learning: "all natural learning experiences and those conscious and planned activities which are intended to be of direct or indirect benefit to the individual, group or school and which contribute...to the quality of education in the classroom" (p. 3). It is this definition that is adopted for this study, incorporating the idea that professional learning occurs as part of PD through a combination of planned and unplanned activities. Characteristics of effective PD will now be explored briefly. 


\section{Characteristics of Effective Professional Development}

Literature on PD describes two common models: (1) traditional type of activities that involve workshops, seminars, and conferences, and (2) reform type activities that incorporate study groups, networking, mentoring, and meetings that occur in-situ during the process of classroom instruction or planning time (Lee, 2007). Although it is suggested that the reform types of PD are more likely to make connections to classroom teaching and may be easier to sustain over time, Lee (2007) argued there is a place for traditional PD or a combination of both, which may work well for teachers at various stages in their careers. This was the approach taken in this study, where teachers were provided with some opportunities to participate in external seminars and conferences as well as tailored and sustained in-situ PD opportunities.

The provision of on-site PD provides a contextually responsive approach, allowing the facilitator of the PD to contextualize to the teacher's site of practice (Garet, Porter, Desimone, Birman, \& Yoon, 2001). Extending this idea, Higgins and Parsons (2011) argued for "situated professional learning opportunities in the teachers' classroom" enabling "facilitators to engage teachers in the PD core ideas and enact these in practice" (p. 55).

The duration of PD has been identified as a significant characteristic of determining its effectiveness (Lee, 2005). The literature refers to duration in terms of providing time, space, and support to develop teachers' confidence, ability, and skills (Darling-Hammond, Wei, Anree, Richardson, \& Orphanos, 2009; Desimone, 2009; Wayne, Yoon, Zhu, Cronen, \& Garet, 2008). Darling-Hammond et al. (2009) and Darling-Hammond, Wei, Chung, Richardson, and Orphanos (2009) suggested changes in teacher practice and student learning occur through "intensive and sustained PD activities, especially when they include applications of knowledge to teachers' planning and instruction, have a great chance of influencing teaching practices and, in turn, lead to gains in student learning" (2009b, p. 44). The literature also supports the argument that well-designed PD is seen to provide classroom support over a sustained period of time (Desimone, 2009; Higgins \& Parsons, 2011), recognizing that change is progressive and requires time and effort (Guskey, 2002).

Another aspect of effective PD that was particularly relevant to Springvale Public School was provision of the opportunity for collective and collaborative participation to build a professional community within the school (Borko, 2004; King, 2014). This is supported by the NSW Institute of Teachers: "Teachers who contribute to their professional growth by participating in collegial professional practice. PD is most effective when undertaken in this manner". Wenger (n.d.) defines communities of practice as "groups of people who share a concern or a passion for something they do and learn how to do it better as they interact regularly". Furthermore, professional collaboration is articulated in the standards set by the 
current professional accreditation body, BOSTES. Other literature supports the building of a professional community through PD as a new paradigm in effective PD, promoting sustained, job embedded, and collaborative teacher learning strategies (Darling-Hammond \& Richardson, 2009). However, Cwikla (2007) cautioned that in order to inspire a community of practice, participants require a central and focused goal to work toward - simply providing space and time is not enough.

\section{Professional Development and Mathematics}

In Australia, mathematics teachers are encouraged to be active lifelong learners. The Australian Association of Mathematics Teachers (AAMT) states: "all educators of mathematics must have the opportunity to access high quality professional learning that promotes a culture of inquiry into teaching practice" (Australian Association of Mathematics Teachers, 2013). There are several issues relating specifically to PD and mathematics that are described in the literature. These include, but are not limited to, issues of accessibility, experience of teachers' professional practice (e.g. teachers at various stages of their teaching careers, as was the case at Springvale Public School), and the stance of the PD types.

Issues of accessibility often arise as a result of the way teachers typically function and practice, in an isolated and insulated environment. Higgins and Parsons (2011) described this as the 'difficult to reach dimension' of accessing teachers' actual practice in light of these isolated norms which "conceal the practices of both the strong and the weak teachers from public observation and exchange" (Cwikla, 2007, p. 555). Ball (1996) viewed this through the lens of the 'challenge of incomplete teacher knowledge' where teachers' pedagogical content knowledge is unable to effectively anticipate, interpret, and respond to students' actual mathematical discourse, understanding, and outcome achievements. Herein, Ball raises issues around teachers' capacity to implement mathematical problems 'in a deeper way' as a means of engaging students with core mathematical concepts, which has been linked to levels of student achievement (Hiebert et al., 2013, as cited in Santagata, Kersting, Givvin, \& Stigler, 2010). Likewise, Santagata et al. (2011) suggested that commonplace teaching of middle school mathematics in the USA "tended to reduce all problems to sets of procedures that required students only to execute routine steps" (p. 2), in contrast to what is understood to be best practice, engaging students in effective and meta-cognitive mathematical discourse and understanding.

A second issue the literature recognizes is a variation in teacher needs and preferred forms of PD in light of their teaching experience and longevity of professional practice. Cwikla (2003) focused on the response and reflections of less experienced teachers finding that the less experienced teacher "might welcome meaningful peer interaction maintaining the collegial attitudes similar to the university atmosphere they have just left" (p. 183) as 
compared to more senior teachers who have grown accustomed to the individualistic and isolated teaching environment and defer to the 'politeness norm' that "dominates most current teacher discourse" (p. 184). As a result, Cwickla recommends PD programs in mathematics structured around peer groups for less experienced teachers, including "content and pedagogy focus sessions, study groups, 'expert' presentations, journal reflections, small group lesson preparation mentoring, classroom observations, and reflection records" (p. 184).

Thirdly, the stance taken by types of PD is viewed as limiting to professional mathematical discourse. Traditional PD (in-service workshops, seminars, meetings) assume a stance toward practice that concentrates on answers: conveying information, providing ideas, training in skills, offering participants a wide range of resources, however, their "potential is restricted by the lack of critical discussion...seeking to make participants comfortable...leaders rarely challenge the teachers' assumptions or provoke disequilibrium" (Ball, 1996, p. 505). As teachers politely "refrain from critique and challenge, they have no forum for debating and improving these understandings" (p. 505), impeding their capacity to grow. Reform PD should foster a stance of critique and inquiry, hence, the leaders and facilitators of PD are influential in instigating a community of learners where inquiry is valued (Borko, 2004).

\section{Methodology}

For the purpose of this paper, the following research questions are addressed:

1. Can sustained and tailored professional development re-engage teachers with mathematics?

2. Did the professional learning program influence and change teachers' practices?

3. What were the teachers' overall perceptions of the professional development program?

\section{Communities of Practices as a Conceptual Framework}

The project methodology is framed within the concept of communities of practice. Wenger (Wenger, n.d.) defines communities of practice as "groups of people who share a concern or a passion for something they do and learn how to do it better as they interact regularly" (p. 1). Participation within a community of practice is an encompassing process of "being active participants in the practices of social communities and constructing identities in relation to these communities... such participation shapes not only what we do but also who we are and how we interpret what we do." (Wenger, 1998, p. 4). Lave and Wenger (1991) acknowledged that learning involves increasing participation within a community of practice that is composed of novices and experts. This social theory of learning aligns well the goal of the school principal in relation to building the capacity of the teachers and the intention of the PD program. This is the lens through which the data was investigated, alongside the Framework for Engagement with Mathematics (Attard, 2014). 
The research aspect of this study utilized case study methodology. The study was located within a social constructivist approach in order to gain insight into the perspectives of the participating teachers in relation to their experiences with sustained PD. A total of eleven teachers participated in the PD program. Data was collected from students but is not presented in this paper. Date was collected from the teachers in the following ways.

- Semi-structured interviews (mid-way and on completion of the project)

- Field notes

Interviews were transcribed verbatim. Data was examined manually for emerging themes or patterns and categorized; this occurred each time data was collected during the course of the study.

\section{Research Site}

Springvale Public School is situated in a low socio-economic area of Sydney's Western suburbs. Twenty-nine per cent of the school's population has a language background other than English and 12\% of the school's population is indigenous. The school academic results were situated in the lowest quartile of the National Assessment Program for Literacy and Numeracy (NAPLAN) for literacy and numeracy. The school's principal had been appointed one year prior to the commencement of the PD program.

\section{Participants}

Although all teachers from Grades 4 to 6 were involved in the PD program, participation in the research aspect of the project was voluntary. All of the teachers accepted the invitation to participate. The teachers ranged in experience from newly graduated up to 30 years' experience. There was one male teacher in the group and he was the only male staff member apart from the school principal. To protect their identity, all participants' names have been removed from the data and the teachers will be identified by codes detailed in the table below (Figure 2). The following table is the list of teachers and their coding.

\begin{tabular}{|c|c|c|}
\hline Teacher & Grade & ID Code \\
\hline 1 & 3 & T1 \\
\hline 2 & 3 & T2 \\
\hline 3 & 3 & T3 \\
\hline 4 & 4 & T4 \\
\hline 5 & 4 & T5 \\
\hline 6 & 4 & T6 \\
\hline 7 & 5 & T7 \\
\hline 8 & 5 & T8 \\
\hline 9 & $5 / 6$ & T9 \\
\hline 10 & 6 & T10 \\
\hline 11 & 6 & T11 \\
\hline
\end{tabular}

Figure 2. Teacher identification codes 


\section{The Professional Learning Program}

The following (Figure 3) is a list of the PD program activities that were implemented at Springvale over the course of the project. Apart from the initial whole school PD session on iPads, the activities were developed over the course of the project in response to the teachers' requests and needs.

\begin{tabular}{|c|c|c|}
\hline Year & Date & Activity \\
\hline \multirow{2}{*}{1} & November & $\begin{array}{l}\text { Provided advice and assistance to school principal in relation to the ordering of } \\
\text { mathematics resources and materials }\end{array}$ \\
\hline & December & $\begin{array}{l}\text { Whole school PD session presented by university academic on using iPads to teach } \\
\text { primary mathematics }\end{array}$ \\
\hline \multirow{10}{*}{2} & February & $\begin{array}{l}\text { Half day sessions with teachers } \\
\text { Content covered: } \\
\text { - Student engagement (introduction of FEM) } \\
\text { - Best practice in the teaching of mathematics } \\
\text { - Using concrete materials to improve engagement }\end{array}$ \\
\hline & March & $\begin{array}{l}\text { Half day sessions with all teachers (teachers split into two groups of grades } 3 \text { and } 4 \text {, } \\
\text { and grades } 5 \text { and } 6 \text { for each half day session during program) } \\
\text { Content covered: } \\
\text { - Needs analysis } \\
\text { - Activities linked to best practice were introduced } \\
\text { Mathematical Association of NSW one day primary conference attended by several } \\
\text { staff }\end{array}$ \\
\hline & May & Demonstration lessons in grade 5 and 6 classrooms \\
\hline & June & Demonstration lessons in grade 5 and 6 classrooms \\
\hline & July & Demonstration lessons in grade 3 and 6 classrooms \\
\hline & August & $\begin{array}{l}\text { Half day sessions with all teachers } \\
\text { Content covered: } \\
\text { - Mathematical investigations } \\
\text { - Introduction of Maths } 300 \text { program } \\
\text { - Linking investigations to the Australian and NSW Curricula. } \\
\text { - Programming approaches were discussed }\end{array}$ \\
\hline & August & Demonstration lesson, grade 6 \\
\hline & September & Demonstration lesson, grade 3 \\
\hline & September & $\begin{array}{l}\text { Half day sessions with all teachers } \\
\text { Content covered: } \\
\text { - Teaching with technology (Probot robotics introduced) } \\
\text { - Maths } 300 \text { (online resource) } \\
\text { - Discussion /reflection of lessons } \\
\text { - NSW syllabus }\end{array}$ \\
\hline & November & $\begin{array}{l}\text { Half day sessions with all teachers } \\
\text { Content covered: } \\
\text { - Reflection on teaching and learning } \\
\text { - Demonstration of concrete materials }\end{array}$ \\
\hline
\end{tabular}




\begin{tabular}{|c|c|c|}
\hline Year & Date & Activity \\
\hline \multirow{4}{*}{3} & April & $\begin{array}{l}\text { Half day sessions with all teachers } \\
\text { Content covered: } \\
\text { - Dealing with the needs of students } \\
\text { - Programming and planning in mathematics }\end{array}$ \\
\hline & May & $\begin{array}{l}\text { Half day sessions with all teachers } \\
\text { Content covered: } \\
\text { - Collaborating to design a unit of work } \\
\text { - Teaching and learning fractions }\end{array}$ \\
\hline & May & $\begin{array}{l}\text { Half day sessions with all teachers } \\
\text { Content covered: } \\
\text { - Working collaboratively on fractions unit of work }\end{array}$ \\
\hline & June & $\begin{array}{l}\text { Half day sessions with all teachers } \\
\text { Content covered: } \\
\text { - Planning unit of work } \\
\text { - Designing rich tasks } \\
\text { - Designing for assessment }\end{array}$ \\
\hline
\end{tabular}

Figure 3. PD activities

\section{Results and Discussion}

At the start of the PD program, there was little evidence of a functional community of practice operating at the school. Each of the teachers programed and planned their mathematics lessons independently, with little or no knowledge of what was occurring in other classrooms. As stated earlier, the staff at the school had received minimal or no PD in the area of mathematics prior to the appointment of their current principal. When asked about their previous experiences of PD, some teachers had experienced one-off, ad-hoc events, however there was a sense that this approach had not been effective. One teacher made the following comment that aligns with Cwilka's (2003) belief that PD imposed from outside schools and classrooms may not match with the agendas or needs of individual teachers:

Well the one-off event only affects that one person and then they can then choose or not choose whether to share it or whether they've been requested to share it, or whether it just gets put and filed away, or whatever it may be. So, I don't think that method works very well at all (T11).

During the first interview, the teachers spoke about how they viewed themselves as teachers of mathematics. Several of the Early Career Teachers (ECTs) reported a lack of confidence and felt challenged in engaging their students with mathematics. One teacher made this comment: "So maths is not my forte; it's not my favorite subject but I feel as though I'm learning with the kids. You know when we get things to do I find that if I can quickly work out how to do it I'm of course a much better teacher, but sometimes I don't”' (T1). Another ECT stated: 
I'm slowly starting to get more confident with it. Some areas I feel like I have a lot more trouble trying to engage the students than others...I can't work out ways to make them as interesting as I can with other aspects (T10).

Given that the development of pedagogical content knowledge occurs over time and with experience and continuing PD, these ECTs required support from colleagues and at that point in time, were working in isolation from other teachers. Other, more experienced teachers, were more confident with their overall teaching skills and mathematical ability, but did not enjoy teaching it or felt restricted by a lack of teaching ideas and resources, as this teacher, T8, expressed: “... maths has always been something I tend to shy away from. I found that early on I'd rely on things like textbooks and worksheets where literacy was always my area".

Of some concern, was the following comment by a Grade 3 teacher, T2, with 10 years of experience: "Lately I've actually felt that when I first came out of uni I was better at teaching mathematics than I am now. In terms of, I was willing to try new things, I was differentiating more." This teacher appeared to be disengaged with the teaching of mathematics due to the mixed messages she received from those teaching around her and the little PD that she had experienced. It also appears that the pressure to conform to existing school cultures may influence ECTs to adapt their practices in order to fit in.

At the final interviews, teachers were asked if they had changed the way the viewed themselves as teachers since experiencing the PD program. The majority of the teachers reported that they felt more confident in engaging their students with mathematics, however one Grade 3 teacher, T1, who claimed that 'maths was not her forte', still lacked confidence, stating: "A lot of the kids in the class are much smarter than me at maths, I know they are". The same teacher also appeared to be struggling with behavior management, which could have interfered with the development of her mathematics pedagogical content knowledge: "I think finding the time with trying to teach my kids manners and not to interrupt and that's hard, because if you're talking to someone who doesn't understand it you've got everyone saying "Miss, miss, miss, that's hard".

Other issues faced by some of the teachers during the course of the PD included the challenge of sharing their practices with other teachers during the sessions. To some, this was intimidating: "I mean, because different people always bring in different ideas ... It sort of makes you feel inadequate to some degree" (T9). The same teacher also found it a challenge to try new things and to adapt and use other teachers' ideas within her own classroom: "We've always been very much like programming and stuff by ourselves so I mean just personally speaking I find it difficult to integrate other people's ideas..."

Although the levels of confidence amongst the teachers were improving, at the conclusion of the program there was still much room for improvement. 


\section{Changes to Pedagogical Practices}

During their final interview, the teachers spoke about how the PD program had influenced their practices. Although several of the teachers were still establishing their pedagogies, all of the teachers claimed their practices had changed to some degree. Many spoke about their changed approach to teaching mathematics and how it had become more student-cantered: "It's more the focus, getting them (the students) to think about why is that the answer, how did they get the answer, could they get a different answer?" (T3), and

... I saw all these great problem-solving ideas and they were the things that really engaged the students and I pretty much last year turned my whole maths teaching around... I think it's changed more in the last 12 months than it did in the 28 years (T8).

Another common theme that emerged was the use of more operatively engaging, hands-on tasks that resulted in the new resources purchased by the school and the way they were demonstrated during the PD sessions:

\footnotetext{
...the kids love that and they learn better... I think you've showed me how to use the resources, the concrete materials which I think is better, because otherwise I would have just done worksheets (T1).
}

A significant aspect of teaching influenced by the PD program was the integrating of mathematical concepts across the mathematics curriculum (rather than teaching topics in isolation) and across other subject areas. Prior to the program, mathematics had been taught in an isolated manner, with no links to other curriculum areas, limiting the students' abilities to understand the relevance of mathematics and its real-world applications. This is an important element of engaging mathematics lessons as identified within the FEM (Attard, 2014): "the relevance of the mathematics curriculum is explicitly linked to students' lives outside the classroom and empowers students with the capacity to transform and reform their lives." The following quote exemplifies the new practices and beliefs of the teachers:

I was teaching just all the strands separately and all the KLA's separately but now I've started to bring them in because you find there's not enough time to do them all separately. But it sort of works better to bring them all in because the kids are getting more out of it. They're picking up on the different things a bit easier because it's not just stand-alone (T4).

\section{Building a Community of Practice}

Wenger (1998) stated some of the indicators that a community of practice has been formed, participants must have a "shared way of engaging in doing things together" (p. 125) and would include "knowing what others know, what they can do, and how they can contribute to an enterprise" (p. 125) and "a shared discourse reflecting a certain perspective on the world" (p. 125). At the start of the PD program at Springvale there was little evidence of the existence of a community of practice, particularly at the level of classroom teaching and learning. This is evidenced in this comment from a Grade 3 teacher (T3): 
We haven't had a lot of that sort of opportunity before it's hard to then work with other people because we're all in our own mindsets...but getting engagement together and getting people's ideas is helping I think.

As a result of the PD program and the activities that provided the opportunity for the teachers to get to know each other on a professional level (they were already familiar on a social level), evidence of an emerging community of practice is seen. The following are some of the quotes that prove this:

\footnotetext{
"...we used to often chat (during the PD program) after school and it was chats about maths actually and what was going on in the class and the activities they were involved in "(T5).

I think being with the staff is the most that I've gained and having an insight to how they think and what they do. Just to see other people's practices and along the way helping others... and I think all of us working together it's amazing because you get so many other viewpoints that you oh, I didn't even think of that, so that's the most I've gained working with staff, I think the opportunities are great and when we work together it's really good because last year there wasn't so much of the collaboration, it was more you go off and do yours and you go off and do yours, so it's insightful (T7).

"I think we're starting now to recognize each other's strengths and to utilize them. I know if I come up with an idea I always run it by... and things like that' (T8).
}

One surprising benefit from the emergence of the community of practice appeared in one of the Grade 4 classrooms where the students also appeared to be developing their own community of practice. The teacher of this group made several comments about how she had focused on increasing the levels of dialogue amongst her students and between herself and her students:

\footnotetext{
I think because of that communication it's really good because now they're starting to use it more in class as well and I try and make sure that we have time to reflect and talk about it more. Because last year when I first started teaching it was more about getting them to do the work rather than talking. So I've now been able to just stop - even if we don't get through it all, we make sure we stop and reflect on what we've done (T4).
}

This practice aligns with the FEM in relation to supporting student engagement, interaction amongst students and between teacher and students is continuous and there is substantive conversations about mathematical concepts and their applications to life (Attard, 2014). The increased dialogue amongst all the members of this class group resulted in more reflective learners and the development of a shared language in relation to the ways students began to see themselves as learners of mathematics.

\section{Changes in Teacher Engagement}

One of the research questions driving this study was: Can sustained and tailored professional development engage teachers with mathematics? Evidence from the data collected suggests this PD program did engage the teachers at Springvale. The program had the biggest impact on one of the most experienced teachers at the school, who made this comment: 
I never considered myself a maths teacher in any way shape or form until this. I've done all the things that I've done, have added to my literacy abilities but I've tended to avoid maths, whereas now I don't. If I go home and I'm looking for activities and you know trolling the Internet for ideas, it's usually maths now rather than literacy. So I'm a lot more confident...it's sort of made me feel a lot more rounded as a teacher...a lot more confidence in maths than I've ever had in thirty years of teaching. It's not just the teaching part of it that's improved. I think it's the whole outlook on maths. And passing that on to those kids particularly the ones that weren't terribly enthusiastic (T8).

Comments from other teachers include: "It's reaffirmed that I'm on the right track and that sometimes having evidence in a book isn't always the evidence that we need to collect" (T5). Many of the teachers spoke about how their engagement with mathematics has improved the engagement of their students, often as a result of their increased use of hands-on resources leading to higher degrees of operative engagement:

We've been really sort of interactive with all the things that we've brought in so the white boards, the cards, the dice; the kids absolutely love sort of doing those things. I try and use those every lesson. We do still do work in our books and things like that but we try and - I try and give them that hands on experience with all of the equipment we have in the classroom (T4).

Another comment relating to the increased use of more interactive tasks as this:

I think they're more engaged now because I think you have opened up the door for the activities to be more visible. Before it may have looked to some teachers that an activity was not learning and someone would come past and say they were playing games. And it's like it's not a game if it's learning and thinking (T7).

Overall, the teachers were now implementing more student-centered tasks that were focused on mathematical processes such as problem solving, reasoning, and communicating, rather than just mathematical content, which is a critical requirement of the current mathematics curriculum document.

As a result of the PD program, the teachers seemed to have gained a much stronger understanding of how to adapt their pedagogical practices to engage students. The resources provided and demonstrated through the sessions as well as the modelling of good practice provided a strong foundation for these teachers and enabled them to view mathematics teaching and learning in a very different way. The following quote exemplifies the general feeling of the teachers:

Engagement is no problem at all...there's no reason for mediocrity to occur anywhere anymore. I'm sure it does, but there's no need - there's no room for it anymore. So the engagement is no issue - there's enough stuff out there to engage them. Is the learning happening? That's another thing all together, and that needs to be carefully monitored and looked at. I like to think it is happening, but I think just the passion for mathematics is starting to show in students like I've never seen before. So that's from the engagement side of things (T11). 


\section{Teachers' Overall Reaction to the Professional Development Program}

During their final interview, the teachers discussed what they had gained from the PD program and spoke about their reactions to the program. The teachers appreciated the use of 'outsiders' to provide professional development as well as the credibility that came with the fact that the facilitators were from a university.

I think it's really good having the expert people come in to help us out - being able to engage with other people at the school - definitely got good potential to do like changes within the school which have been missing for a long time (T3).

There was a sense that the teachers felt they were now on the right track in terms of being engaged and engaging their students:

You have brought insight into the school of what works, what's maybe not working, how we can challenge ourselves rather than just the children and putting us into that spot where you have to sort of get in there and investigate, I because you can't teach it unless you do it yourself (T5).

\section{Conclusion}

Although this study was limited in terms of being a single case study, findings may be generalizable to other teachers and school contexts. Though the PD program was a success, it was not without its challenges. Being invited into a school over a sustained period of time with permission to tailor the PD to the needs of the teachers is not as simple as it may seem. Deciding where to begin was not easy, however the fact that the school had very few resources for the teachers to access provided a starting point and allowed the facilitators to begin the PD program by illustrating the FEM (Attard, 2014) through demonstrating the new resources that had been purchased. Further research into the design of tailored mathematics PD would be of benefit to the profession.

The findings from this research align with recommendations from literature that teachers must have the opportunity to participate in PD throughout their careers. This is particularly critical for early career teachers who are in the early stages of developing their mathematics pedagogical content knowledge. The teachers at Springvale Public School had already begun to adapt their practices as a result of the PD they had received through this project. However, further PD is important to maintain the momentum gained. It is also recommended that teachers be provided with a range of PD opportunities that include selfnominated PD and PD that is focused on individual needs as well as group needs.

\section{References}

Attard, C. (2011). The influence of teachers on student engagement with mathematics during the middle years. Paper presented at the $34^{\text {th }}$ Conference of the Mathematics Education Research Group of Australasia, Alice Springs, NT. 
Attard, C. (2012). The influence of pedagogy on student engagement with mathematics during the middle years of schooling. In A. L. White, \& U. H. Cheah (Eds.), Transforming school mathematics education in the $21^{\text {st }}$ century (pp. 140-157). Penang: SEAMEO RECSAM.

Attard, C. (2014). "I don't like it, I don't love it, but I do it and I don't mind": Introducing a framework for engagement with mathematics. Curriculum Perspectives, 34(3), 1-14.

Australian Association of Mathematics Teachers. (2013). AAMT position paper on professional learning. Retrieved from http://www.aamt.edu.au/Publications-andstatements/Position-statements/Professional-Learning

Australian Curriculum and Reporting Authority. (2017). Australian curriculum: Mathematics F-10. Retrieved from http://www.australiancurriculum.edu.au/Mathematics/Curriculum/F-10

Ball, D. (1996). Teacher learning and the mathematics reforms: What we think we know and what we need to learn. Phi Delta Kappan, 77(7), 500-508.

Board of Studies New South Wales. (2012). Mathematics K-10 syllabus. Retrieved from http://syllabus.bos.nsw.edu.au/

Borko, H. (2004). Professional development and teacher learning: Mapping the terrain.

Educational Researcher, 33(8), 3-15.

Commonwealth of Australia. (2008). National numeracy review report. Retrieved from: http://www.voced.edu.au/content/ngv\%3A19994

Cwikla, J. (2007). The trials of a poor middle school trying to catch up in mathematics: Teachers' multiple communities of practice and the boundary encounters. Education and Urban Society, 39(4), 554-583.

Darling-Hammond, L., \& Richardson, N. (2009). Research review/teacher learning: What matters. Educational Leadership, 66(5), 46-53.

Darling-Hammond, L., Wei, R., Andree, A., Richardson, N., \& Orphanos, S. (2009). Professional learning in the learning profession. Washington, DC: National Staff Development Council.

Desimone, L. (2009). Improving impact studies of teachers' professional development: Toward better conceptualizations and measures. Educational Researcher, 38(3), 181199.

Fair Go Team NSW Department of Education and Training. (2006). School is for me: Pathways to student engagement. Sydney: NSW Department of Education and Training, Sydney, Australia.

Fredricks, J. A., Blumenfeld, P. C., \& Paris, A. H. (2004). School engagement: Potential of the concept, state of the evidence. Review of Educational Research, 74(1), 59 -110.

Garet, M., Porter, A., Desimone, L., Birman, B., \& Yoon, K. (2001). What makes professional development effective? Results from a national sample of teachers. American Educational Research Journal, 38(4), 915-945. 
Guskey, T. (2002). Professional development and teacher change. Teachers and Teaching: Theory and Practice, 8(3), 381-391.

Higgins, J., \& Parsons, R. (2011). Professional learning opportunities in the classroom: Implications for scaling up system-level professional development in mathematics. Mathematics Teacher Education and Development, 13(1), 54-76.

King, F. (2014). Evaluating the impact of teacher professional development: an evidencebased framework. Professional Development in Education, 40(1), 89-111.

Lave, J, \& Wenger, E. (1991). Situated learning: Legitimate peripheral participation. New York: Cambridge.

Lee, H. (2007). Developing an effective professional development model to enhance teachers' conceptual understanding and pedagogical strategies in mathematics. Journal of Educational Thought, 41(2), 125.

Mayer, D, \& Lloyd, M. (2011). Professional learning: an introduction to the research literature. Australian Institute for Teaching and School Leadership, Melbourne. Prepared in partnership with Deakin University and the Queensland University of Technology. ISBN, 978-970.

Munns, G, \& Martin, A. J. (2005). It's all about MeE: A motivation and engagement framework. Paper presented at the Australian Association for Academic Research Focus Conference, Cairns. Retrieved from http://www.aare.edu.au/05pap/mun05400.pdf

Rim-Kaufman, S., Baroody, A., Larsen, R. Curby, T., \& Abry, T. (2014). To what extend do teacher-student interaction quality and student gender contribute to fifth graders' engagement in mathematics learning? Journal of Educational Psychology, 107(1), 170-175.

Santagata, R., Kersting, N., Givvin, K., \& Stigler, J. (2010). Problem implementation as a lever for change: An experimental study of the effects of a professional development program on students' mathematics learning. Journal of Research on Educational Effectiveness, 4(1), 1-24.

Wayne, A., Yoon, K., Zhu, P., Cronen, S., \& Garet, M. (2008). Experimenting with teacher professional development: Motives and methods. Educational Researcher, 37(8), 469479.

Wenger, E. (1998). Communities of practice: Learning, meaning, and identity. Cambridge: Cambridge University Press.

Wenger, E. (n.d.). Communities of practice: A brief introduction. Retrieved from http://wenger-trayner.com/theory/ 